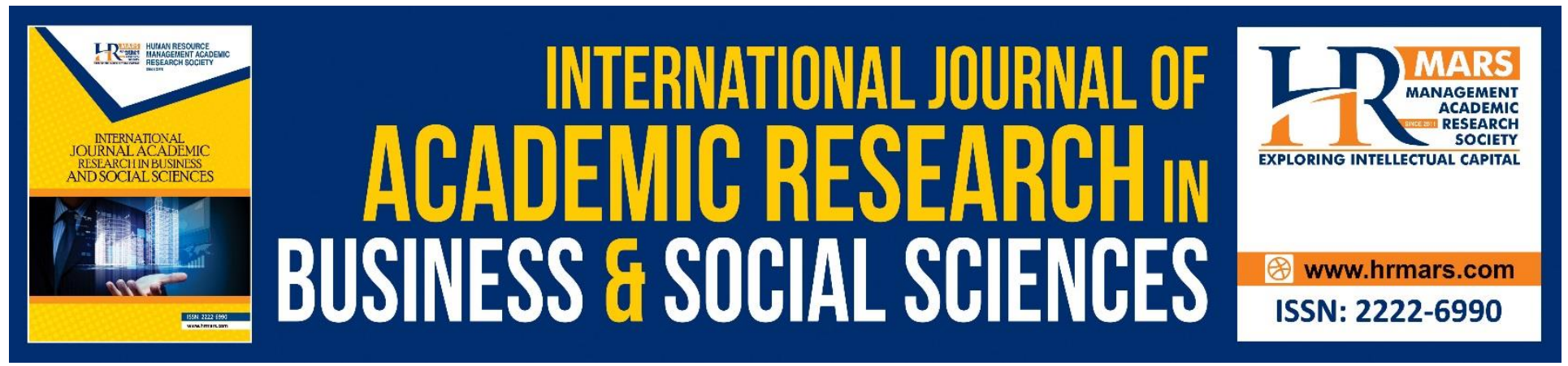

\title{
The Interactive Effects of Entrepreneurial Orientation, Islamic Values and Business Success: A Conceptual Study
}

Zainatulhani Mohamad, Mohamad Zulkifli Bin Abdul Rahim, Habsah Muda, Roslida Razak, Mohd Rosli Mohamed, Abdul Malek Tambi, Hartini Abdul Ghani

To Link this Article: http://dx.doi.org/10.6007/IJARBSS/v8-i8/4478

DOI: $\quad 10.6007 /$ IJARBSS/v8-i8/4478

Received: 09 August 2018, Revised: 26 August 2018, Accepted: 30 August 2018

Published Online: 09 September 2018

In-Text Citation: (Mohamad, Rahim, Muda, Razak, Mohamed, Tambi \& Ghani, 2018)

To Cite this Article: Mohamad, Z. (2018). The Interactive Effects of Entrepreneurial Orientation, Islamic Values and Business Success: A Conceptual Study. International Journal of Academic Research in Business and Social Sciences, 8(8), 410-425.

Copyright: (C) 2018 The Author(s)

Published by Human Resource Management Academic Research Society (www.hrmars.com)

This article is published under the Creative Commons Attribution (CC BY 4.0) license. Anyone may reproduce, distribute, translate and create derivative works of this article (for both commercial and non-commercial purposes), subject to full attribution to the original publication and authors. The full terms of this license may be seen at: http://creativecommons.org/licences/by/4.0/legalcode

Vol. 8, No. 8, August 2018, Pg. 410 - 425

http://hrmars.com/index.php/pages/detail/IJARBSS

JOURNAL HOMEPAGE

Full Terms \& Conditions of access and use can be found at http://hrmars.com/index.php/pages/detail/publication-ethics 


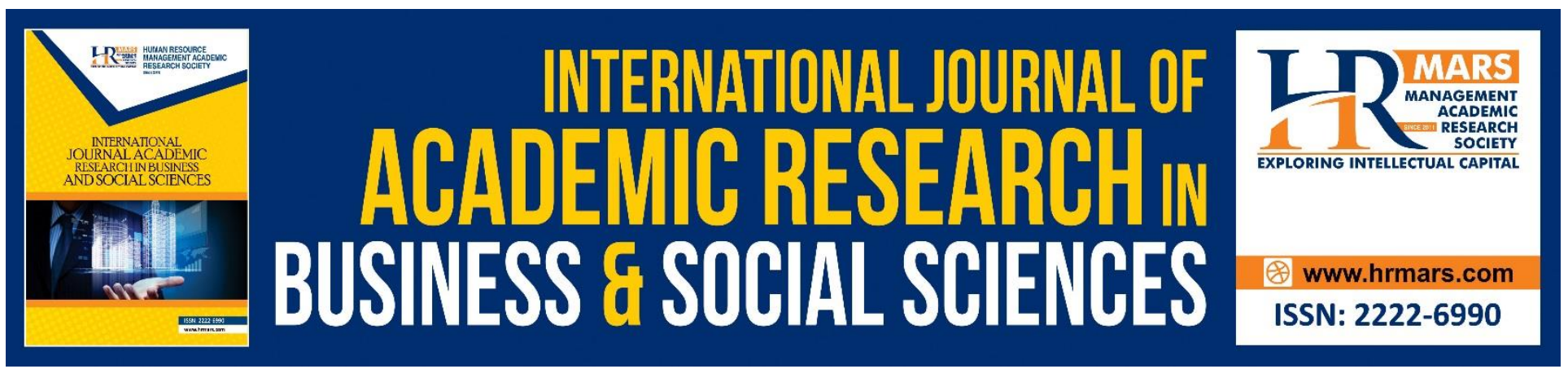

\title{
The Interactive Effects of Entrepreneurial Orientation, Islamic Values and Business Success: A Conceptual Study
}

\author{
Zainatulhani Mohamad, Zulkifli Rahim, Habsah Muda, Roslida \\ Razak, Mohd Rosli Mohamed, Abdul Malek Tambi, Hartini Abdul \\ Ghani
}

Faculty of Economy and Management, Universiti Sultan Zainal Abidin (UniSZA)

Email: zainatulhanimohamad93@gmail.com

\begin{abstract}
It is undeniable, the Small and Medium Enterprises help much in boosting the economic growth in many countries. Hence, many scholars have studied on its success factors throughout different perspectives, including Entrepreneurial Orientation, Islamic values and business success. However, past studies revealed contradictory results on EO and business success relationship. Furthermore, limited empirical studies on the effect of Islamic values were found in the context of SMEs especially the Malay entrepreneurs. Accordingly, this study aims to examine the interactive effects of EO on business success with the integration of moderation effects of Islamic values of Trustworthiness (Amanah), Truthfulness (Siddiq), Communicative (Tabligh) and Wisdom (Fathonah). Besides, this study will contribute to the selected theories of Islamic Leadership Theory and Human Capital Theory. The development of the theoretical model is expected to shed a new light of the constructs under reviewed and would elevate the business success among Malays SMEs.
\end{abstract}

Keywords: Entrepreneurial Orientation, Business Success, Islamic Values, Truthfulness, Wisdom, Honesty, Communicative, Malay Entrepreneurs.

\section{Introduction}

In Malaysia, the contribution of Small and Medium Enterprises (SMEs) continues to grow significantly. The SMEs consists over $90 \%$ of the Malaysia business sectors (Bakar, Daud, Awaludin, \& Jaafar, 2016). Ahmad and Mohamed Zabri (2015) acknowledged the huge potential of SMEs to the country as the key driver for economic growth, many studies (Keh, Nguyen, \& Ng, 2007; Boso, 2010; El-Annan, 2013; Abdul Rahman, Yaacob, \& Mat Radzi, 2014; Banta, 2015; Matchaba-Hove, Farrington, \& Sharp, 2015) have been done to examine the business success factors. Furthermore, Lans, Blok and Wesselink (2014) suggested entrepreneurs as the mover of SMEs, must be equipped with specific knowledge, skills, techniques, and ability to conduct and motivate towards their business goals. Besides, 
INTERNATIONAL JOURNAL OF ACADEMIC RESEARCH IN BUSINESS AND SOCIAL SCIENCES

Vol. 8, No. 8, August 2018, E-ISSN: 2222-6990 @ 2018 HRMARS

entrepreneurs must be resilient toward unforeseen circumstances (Ayala \& Manzano, 2014; Bullough, Renko, \& Myatt, 2014). For example, they have to earnestly anticipate in capturing all business opportunities to perform better in business discipline (Dana, Gurau, \& Lasch, 2014). Even though a lot of studies have been done to understand the success factor, past studies only emphasized on the issues of; eg lack of management skill (Abdul Rahman, Yaacob, \& Mat Radzi, 2014b), marketing strategies (Zendehdel, Hj Paim, \& Delafrooz, 2016), financial problem (Salikin, Wahab, \& Muhammad, 2014; Umrani \& Johl, 2016) and many other entrepreneurial problems. Unfortunately, limited results were found in the literature of EO, Islamic values and business success relationship. This study is conducted to analyse the fall back of Malays SMEs entrepreneurs whom are still lagged behind compared to their business counterparts. Thus, it aims to examine the relationship of EO and business success, and the moderating effect of Islamic values.

\section{Literature Review}

\section{Entrepreneurial Orientation}

Entrepreneurial Orientation (EO) is an important construct in current research of entrepreneurship and has inspired practitioners and scholars over 30 years ago (Hughes \& Morgan, 2015). According to Covin and Slevin (1988), EO consists of the dimensions of innovativeness, proactiveness and risk taking. These dimensions are crucial indicators in achieving a successful business (Arshad et al, 2014).For example, Lumpkin \& Dess $(1996,2001)$ stressed that these dimensions would give significant impacts on business success (Callaghan \& Venter, 2011). As accentuated by Mohamad and Kassim (2017); Nason and Wiklund (2018); Pittino, Visintin and Lauto (2017), they acknowledged EO which consists of innovation, proactiveness and risk taking had positive impact towards SMEs and in fact, many literatures found a significant effect of EO and business success relationship. Nevertheless, past literatures conjointly reported insignificant and mixed results of EO and business success relationship (Umrani, Mahmood, \& Ahmed, 2016). Thus, it has encouraged Wiklund (1999) to further investigate upon the EO-business success relationships. Finally, (Hariri \& Osman, 2006; Piirala, 2012; Shein, Crous, \& Schepers, 2010; Jelenc, Pisapia, \& Ivanusic, 2016) also revealed ineffective result among the relationship and compulsory for further exploration.

\section{Business Success}

Business success can be defined as the firm ability to sustain and uphold in business nature (Hyder \& Robert, 2016). Somehow, different scholars defined business success differently. Baron and Kenny (1986) argued that the determinant of business success or business failure is a complex, dynamic and problematic issues as it requires numerous variables to measure on the construct. Rauch, Wiklund, Lumpkin and Frese (2004);Lucky, Olesegun and Bakar (2012); Galli (2013) view the perception of success can be identified from many angles like, external and internal factor as well as subjective and objective criteria. As such, scholars have linked the business success from external factors like economy and capital markets and cultures (Tehseen, Sajilan, Ramayah, \& Gadar, 2015), while for internal factor includes the cognitive perspectives (Frese et al., 2007; Bayrón, 2013; Salehi \& Roshandel, 2013; Pittino, Visintin, \& Lauto, 2017).

In addition, in terms of business success measurement, numerous studies have reported diverse dimensions to measure business success. Harif, Hoe and Ahmad (2013); Adiana, Ahmad, Md. Rus and Zainudin (2014); Shamsuddin (2014) used both measurements; financial and non-financial measure due to comprehensive attribute in the sense that measure the accurate and authentic success of the 
INTERNATIONAL JOURNAL OF ACADEMIC RESEARCH IN BUSINESS AND SOCIAL SCIENCES

Vol. 8, No. 8, August 2018, E-ISSN: 2222-6990 @ 2018 HRMARS

entrepreneurs. Some studies include subjective criteria for business success such as freedom and independence in controlling the business. For example, Fararah and Al-Swidi (2013); Chokesikarin (2014); Kashif, Awang, Walsh and Altaf (2015); Wijetunge (2016) described factors such as service and quality, dedication and hard work and innovation were crucial to succeed respectively. In addition, Chokesikarin (2014); Suci (2015); Rizki, Armanu, Surachman and Rofiaty (2017) suggest that the firm success and effectiveness should not only be measured in term of objective criteria only like profit, firm's financial performance sales turnover and personal income and wealth; but also based on subjective criteria like the work satisfaction and customer satisfaction.

\section{Islamic Values}

Islam as the way of life is guided by the teaching of the Al-Qur'an and Al-Sunnah (Musa, 2011; Ratten, Alamanda, Ramadani, Hashani, \& Anggadwita, 2017). The Islamic concept of life involves the equality and socio economic justice among human being. Islam encourages all Muslims to be active and hardworking as it reflects the characteristics of true Muslim. As entrepreneurship and business is an integral part of the religion that emboldens wealth and prosperity through the correct usage of the resources, Islam underpinned several principles to be adhered (Arslan, 2009; Al-Aidaros, Shamsudin, \& Idris, 2013; Rahman, Abdullah, Adham, \& Mat, 2014). Prophet Muhammad (SAW) himself is a successful businessman has inculcates the value of Al-Amin that consists of Trustworthy (Amanah), Communicative (Tabligh), Honesty (Siddiq) and Wisdom (Fathonah) in conducting business (Abdullah \& Mikail, 2013; Banta, 2015; Triyuwono, 2006). He is known for integrity. He practices Islamic teaching as resembles by verses (Al-An'aam: 141); saying:

"Don't waste your wealth; those who involved in misusing wealth are the brothers of the evil". In another verse Allah SWT dictates that;

"When your prayer is over, spread over the earth and the bounty of Allah" (Al-Jummu'a:10).

Besides, Prophet Muhammad (pbuh) states that, nine-tenth of the livelihood comes from business activities. With the guidance from Al Qur'an and Al-Sunnah, it will help the entrepreneurs to delegate their business framework accordingly. It is also important to distressed the aims of Islam is for both worlds; this world and hereafter. Somehow, Mohd, Kirana, Kamaruddin, Zainuddin and Ghazali (2014)found that Islamic values affect business success, but these values are not empirically examined, thus this study would like to empirically investigate upon the issues.

\section{Dimensions of Islamic Values}

\section{Trustworthiness (Amanah)}

According to Ascarya and Rahmawati (2015b), Muslim entrepreneurs must have faith in Allah (taqwa) and worship Him by following His command and left what's being forbid. By practicing the two pillars of Islamic laws which are fardhu' ain and fardhu' kifayah, an individual's act of faith of Muslims can be elevated. As such, Fardhu' ain refers to where the act is being practiced by individual. While for fardu kifayah, it is obligated to be performed by the whole societies. Instead of conducting the five pillars of Islam in this life, another aspect of high moral values can improve individual and entrepreneurs by practicing the values in their entrepreneurial activities as practiced by Prophet Muhammad pbuh in his daily life which is Trustworthiness (Amanah).

Trust is the element that shaped positive connection for interpersonal relationship as it decree the linkage of how people communicate to one another. Trust is the key element for accountability as it being highlighted in Al-Quran and Hadith. This value reflects a person intentions with Allah as in the business scope, when the workers trust their employees and believes in what they are doing is right, 
INTERNATIONAL JOURNAL OF ACADEMIC RESEARCH IN BUSINESS AND SOCIAL SCIENCES

Vol. 8, No. 8, August 2018, E-ISSN: 2222-6990 @ 2018 HRMARS

they will achieve their work satisfaction, thus will enhance the business success (Sulaiman, Sabian, $\&$ Othman, 2013). As mentioned by Allah in His Holy Quran in Surah Al-Talaq: 3:

"And He provides for him from (sources) he never could imagine. And if anyone puts his trust in Allah (SWT), sufficient is (Allah) for him, for Allah (SWT) will surely accomplish His purpose verily for all things has Allah (SWT) appointed a due proportion" (Holy Quran, 65:3)

On top of that, taqwa which is the element of Amanah, educate Muslims to endorse and practices the trust (Amanah) (Sarif, 2016). With taqwa and amanah, it will help Muslims to rely solely on Allah SWT without any doubt. It helps Muslims to have trust with no doubt on Allah. With taqwa, it will strengthen the value of trust (Amanah) in individual's life. As such, those who are involve in business sector, taqwa and Amanah will guide them to conduct the business progressively and fairly.

\section{Honesty (Siddiq)}

Siddiq means honesty. An honest people are the one who remain true to themselves and always follow good attitude and always be grateful being the servant of Allah (God) (Ghoniyah \& Hartono, 2014). For Muslim entrepreneurs, it is advisable for them to carry the behavior of truth, honesty and be firm and fair in managing their business and employees.

In Qur'an Surah Al-An'am: 152 gives explanation that the Islamic view of fairness is the source of truth and justice from the heart to be actualized for themselves, others and God.

"And do not approach the orphan's property except in a way that is best until he reaches maturity. And give full measure and weight in justice. We do not charge any soul except [with that within] its capacity. And when you testify, be just, even if [it concerns] a near relative. And the covenant of Allah fulfill. This has He instructed you that you may remember"

In addition, in Surah Hud verse 18, God gives instructions to be fair and honest, as it will lead people to be loved by God who will give glory and fortune in the world and the hereafter.

"And who is more unjust than he who invents a lie about Allah? Those will be presented before their Lord, and the witnesses will say, "These are the ones who lied against their Lord." Unquestionably, the curse of Allah is upon the wrongdoers."

\section{Communicative (Tabligh)}

Tabligh can be defined as communicative. Information must be conveyed properly and accurately as a means of internal control as if there are any failure in conveying the messages or information, it would affect the whole progress of the business. Tabligh teaches entrepreneurs to be ethical in delivering or sharing the thoughts or knowledge. The knowledge must be transparently delivered without any hindered messages. The opinion they made resembles their responsibility where it has been shown by our Prophet Muhammad PBUH before, to be a noble and generous in delivery knowledge. Excellent entrepreneurs are assumes as excellent leader when they managed to carry their business and the workforces to reach the mission, vision and objectives successfully (Putra, 2014). In fact, entrepreneurship in Islam must possess the value of transparency/communicative in conducting business. Transparent entrepreneur is the one who able to communicate accurately and effectively with people regardless of the level or strata. A successful entrepreneur able to motivate, inspire and become an idol for communities, thus, it may benefit many parties.

\section{Wisdom (Fathonah)}

Fathonah refers to the knowledge possess within a person for a comprehensive knowing about human being, circumstances that they are able to choose or react properly in order to create optimum results in an accurate time, with less waste of time and energy. The entrepreneurs who 
possess this attitude will be effective and efficient in conducting their business. This value can be gained through experience and the decision made by the entrepreneurs should be wisely-made. The entrepreneurs are considered as wisdom when they managed to be smart, good in doing decision and very knowledgeable in doing their business in highly competitive business environment (Abdullah \& Ahcene, 2011).

According to Putra (2014) wisdom conveyed the meaning of intelligent. Putra (2014) highlighted that Prophet Muhammad (PBUH) is really wise and extraordinary intelligence as he able to conduct the words of Allah and has attracted so many followers to practice Islamic acts. With the same kind of value, it can be implemented in business strategies. By possessing this value, it would help entrepreneurs to solve business problems as well as making wise solution without segregate other parties, thus, it will be very helpful in conducting the business plan accordingly.

\section{The Relationship between Entrepreneurial Orientation and Business Success}

Abundance of literature on EO and BS provide the answers of its implications for entrepreneurs. Lumpkin and Dess (1996b) acknowledge the positive relationship between EO and firm performance. EO is said to have a significant impact on the firm's performance as it helps the firm to establish the ideas, developing new products or services, get involve in risky projects and be able to capture the business opportunities. The dimensions of EO which are innovativeness, risk taking and proactiveness will be used to discover its effect on the business success. Positive results were indicated from the previous studies (Lumpkin \& Dess, 1996b; Wiklund and Shepherd (2003); Rauch et al., 2004; Salima. Hafeez, Rashid, Zafar and Rehman, 2011) thus, this study posits that; EO has a significant and direct effect on business success.

\section{H1: Entrepreneurial orientation has a significant direct effect with business success}

\section{The Relationship between Islamic Values and Business Success}

Tahir and Abdul (2013) stated that many researchers are fascinated on the field of personality psychology. On their study, they developed a measure of Islamic Personality Model that will benefit the researchers for their general and Islamic research. It is indicated that religious orientation variable had a positive effect on the performance regardless of their gender (Tahir \& Abdul, 2013). On the other hand, other study found that there are five variables consists of Islamic business practices, Islamic work ethics, Muslim worldview, Muslim personal help and Muslim practices have a positive effect on the entrepreneurs' success (Wahab \& Rafiki, 2014). It proves that, Islamic values, ethics and belief are positively related to business success (Rafiki \& Wahab, 2013; Rafiki \& Wahab, 2014). However, previous studies do not provide a comprehensive or unified explanation of Islamic values, therefore, there are many questions still need to be discovered and warrant further explanation.

\section{The Relationship between Trustworthiness and Business Success}

According to Mohamad and Mukhazir (2008) it has been reminded in the verse of Al-Quran; "Those who are faithfully true to their amānah (all the duties which Allah has ordained with honesty, moral responsibility and trust etc.) and to their covenants" (Al-Qur'an: Al-mu'minun 23:8).

It is a duty of Muslims to be vulnerable in conducting any actions and to put aside all the wrongdoings. To do so, entrepreneurs must be faithful and truthful in undertaking business activities. Trust (Amanah) is the concept of accepting responsibility from a Divine commandment as it engages with 
INTERNATIONAL JOURNAL OF ACADEMIC RESEARCH IN BUSINESS AND SOCIAL SCIENCES

Vol. 8, No. 8, August 2018, E-ISSN: 2222-6990 @ 2018 HRMARS

the relationship among human being and Lord. In entrepreneurial concepts, Muslim entrepreneurs must be able to perform their entrepreneurial tasks by using the resources firmly and legally with Islamic conduct. When person is able to fulfil God's command, he is said to reach the value of Amanah (Aminuddin et. al, 2016).

On top of that, Mohamad and Mukhazir (2008) acknowledged that our Prophet (pbuh) embolden Muslims to embroil in business as he stated that,

"You ought to be engaged in commerce because ninety-nine per cent of the bounties of God are contained therein."

Therefore, it is encouraged for businessman to fulfil his obligation as Prophet Muhammad (pbuh) did before.

$\mathrm{H} 2 \mathrm{a}$ : Trustworthiness (Amanah) moderates the relationship between Entrepreneurial Orientation and Business Success

\section{The Relationship between Honesty and Business Success}

As stated by Ajuna, Nasution and Yusuf (2017), honesty (siddiq) is reflected by the act of honesty and fair mind. Frankly, the value of Siddiq resembles the acts of being transparent to ourselves and others. The objective of Siddiq value is to avoid fraudulent and blackmail. Precisely, Muslim entrepreneurs are obligated to manifest the act of honesty in business transactions such as by providing legal information like the attachment of Halal requisite in the packaging and by being consistency when delivering good quality services.

In business, it is important for entrepreneurs to be vulnerable towards any circumstances and manager should be honest in delivering his products and services to the society as well as to stakeholders (Ghoniyah \& Hartono, 2014). In Al-Quran, Al-An'am verse 152 stated that:

"Fairness or justice is the key for honesty and it only comes from a good heart and only can be estimated by God". Additionally, one who always practices justice and honesty will be loved by Allah in world and hereafter. Besides, Kamaluddin et al., (2018) stated that the engagement of clean business transactions leads to a good business access among entrepreneurs. Therefore, entrepreneurs with Siddiq value will be respected more in dealing business. In Al-Quran acknowledged that:

"Truly the best of men to employ is the man who is strong and trustworthy." The Qur'an (28:26) In fact, it is believed that man possession of anything in this world should be shared among others because none of them belongs solely to human beings. From Allah it all belongs, to Allah it all shall return. We are only servant in this world whom is entrusted to carry this wealth or any tasks firmly and fairly.

$\mathrm{H} 2 \mathrm{~b}$ : Honesty (Siddiq) moderate the relationship between Entrepreneurial Orientation and Business Success

The Relationship between Communicative and Business Success

Ajuna et al., (2017) defined Tabligh as an effective communication, good public serving such as giving a good example in delivering the tasks. While Rizki, Armanu, Surachman, \& Rofiaty (2017) emphasized that communicative (tabligh) is the ability to gently communicate and conveying information in a easiest manner to be understood by targeted the person. Allah has reminded us in Al-Quran to be gentle even though when dealing with the foe, as stated in Surah Thaha, Verse 43 and 44: 
INTERNATIONAL JOURNAL OF ACADEMIC RESEARCH IN BUSINESS AND SOCIAL SCIENCES

Vol. 8, No. 8, August 2018, E-ISSN: 2222-6990 @ 2018 HRMARS

"Go, both of you, to Pharaoh. Indeed, he has transgressed. And speak to him with gentle speech that perhaps he may be reminded or fear (Allah)." (Surah Thaha, Verse 43 and 44)

Additionally, Allah SWT does not like harsh words as he stated in Al-Quran:

"Call upon your Lord in humility and privately; indeed, He does not like transgressors." Al A'raf Verse 55

In business, communication (tabligh) is prerequisite in order to achieve a successful business (Mohd Ariffin, Archer, \& Karim, 2007). A good leader must be able to demonstrate leadership, convey or deliver the duty properly and able to create something that give advantages for people and nature as well (Banta, 2015). Hence, it can be simplified that a good entrepreneurs are the one who can motivate and bring out something good for the company as a whole. He or she may be the idols for the work forces and able to be gentle even to the bottom part the worker in the organization as he is able to convey the responsibility appropriately. With Tabligh, any issues arise can be handled gently, peacefully and the solution made would be easy.

$\mathrm{H} 2 \mathrm{c}$ : Communicative (Tabligh) moderates the relationship between Entrepreneurial Orientation and Business Success

\section{The Relationship between Wisdom and Business Success}

Fathonah can be defined as knowledgeable (Wan Daud, Abdul Rahim, \& Mohd Nasurdin, 2017). Ajuna et al. (2017) added, a person is recognized as knowledgeable when he possesses expansive information, skilful and able to design good strategy for his business Moreover, Wan Daud et. al, (2017) stated that successful businessman are the one who are sophisticated in various aspects like political awareness, economic growth, good in education and skilful. Besides, with knowledge, it will help them to be competitive advantage and able to capture the business opportunities through the right medium and correct approaches (Nasimi et al.,2013; Omerzel \& Gulev, 2011; Rahimli, 2012).Therefore, Muslims entrepreneurs must be equipped with knowledge in most facets way because it is crucial for them to understand and utilized the conduct of Syariah as Islamic law as it is important for them to captivate the unambiguous situation and consider the situation as the opportunity for them to attract more profit, only for the sake of Allah SWT.

$\mathrm{H} 2 \mathrm{~d}$ : Wisdom (Fathonah) moderates the relationship between Entrepreneurial Orientation and Business Success

\section{Methods}

In this study, cross-sectional approach will be used to examine the interaction between entrepreneurial orientation, Islamic values and business success. The unit of analysis would be either the founder/owner or manager of the firm. Simple random sampling will be used for data collection from the list of SME Corp. The sample will be drawn from SMEs entrepreneurs in Klang Valley, of Malaysia with at least three years business experience. Self-administered questionnaires will be distributed to the target population. The firm size and firm age will be treated as controlled variables.

\section{Data Analysis}

The data will be analysed by using SEM (AMOS) version 21. Prior to that, the pre-test will be conducted to examine content validity and the relevant items to be used. Followed by pilot study where the questionnaires will be distributed among 100 respondents. The data then will be polished by undergoes the EFA analysis. The number of items would be deducted to the most accurate amount 
INTERNATIONAL JOURNAL OF ACADEMIC RESEARCH IN BUSINESS AND SOCIAL SCIENCES Vol. 8, No. 8, August 2018, E-ISSN: 2222-6990 @ 2018 HRMARS

and only the most suitable items will be selected. Thus, checklist for accuracy for each item will be developed. Any irrelevant items below the requirement of EFA will be dropped. Then, the actual study will be scanned through for data cleaning before final analysis by using Confirmatory Factor Analysis (CFA) and Structural Equation Modelling AMOS. The duration allocated for data collection would be two months.

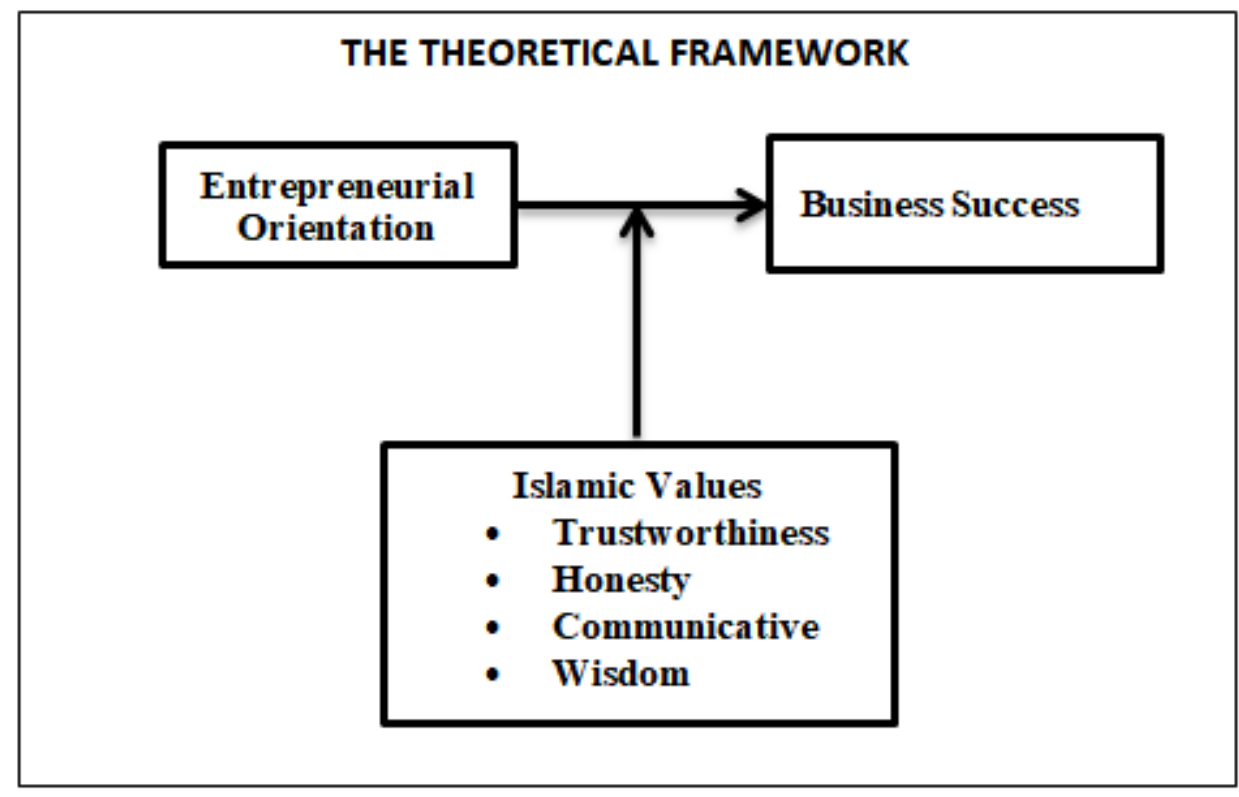

$\mathrm{H} 1$ : Entrepreneurial Orientation has a positive and significant effect on Business Success

H2a: Trustworthiness moderates the relationship between Entrepreneurial Orientation and Business Success

$\mathrm{H} 2 \mathrm{~b}$ : Honesty moderates the relationship between Entrepreneurial Orientation and Business Success

$\mathrm{H} 2 \mathrm{c}$ : Communicative moderates the relationship between Entrepreneurial Orientation and Business Success

$\mathrm{H} 2 \mathrm{~d}$ : Wisdom moderates the relationship between Entrepreneurial Orientation and Business Success

\section{Contribution of the study}

This study is conducted in order to examine the effect of EO and Islamic values on business success. Generally, this study will contribute to the Human Capital Theory and Islamic Leadership Theory. As for Human Capital theory, it is hope that it would give the new insight on the influence of entrepreneurs practising the entrepreneurial orientation at the individual level on their organisational performance. Apart from that, the Islamic Leadership Theory it would be able to explain the influence of practise Islamic values derived from Al-Quran and Al-Sunnah as the guideline in managing the business as the decision must be aligned with Islamic principle (Aabed, 2006).

The study also aiming in improving human condition especially for entrepreneurs, helping them to make better decisions, improve some policy for their firms, and finally help in doing advance decisions making related to the human psychology related with Islamic values. In addition, this research is conducted in order to help Malaysian SMEs to enhance their understanding in the business as well as to fill in the gap of the body of knowledge as regards the effect of the business success and its relationship with entrepreneurial orientation as moderated by Islamic values. 
INTERNATIONAL JOURNAL OF ACADEMIC RESEARCH IN BUSINESS AND SOCIAL SCIENCES

Vol. 8, No. 8, August 2018, E-ISSN: 2222-6990 @ 2018 HRMARS

Further, within the dimensions of innovativeness, risk-taking and pro-activeness; the result from the analysis is expected to reveal which dimension is the main predictor for business success. The study moderates the relationship of EO and Business Success with Islamic values. We want to identify whether there is still exist the transparency among entrepreneurs in conducting their business. We believe that Islamic Values will be the best indicator to analyse the behaviour of those Malay entrepreneurs.

\section{Conclusion}

This study had identified the role of Islamic values and entrepreneurial orientation as the factor on business success among Malay SMEs entrepreneurs in Malaysia. The fundamental objectives of this study are to 1) identify the impact of the relationship between entrepreneurial orientation and business success and to 2) determine the moderating roles of Islamic values; Trustworthiness (Amanah), Siddiq (Truthfulness), Tabligh (Courtesy) and Fathonah (Wisdom) between EO and business success.

It would be assumed that the success factor of the SME is highly dependent on the EO possessed by the entrepreneurs themselves like being innovation, dare to take the risk and being the able to proactively grab the opportunities for future business success. On the other hand, the Islamic values should not be neglected in order build up the rules in gaining profit and success. Generally, moderation effect of Islamic value would prove the essentiality of adopting transparency, being faithful, effective communication and good decision making of the entrepreneurs as the factors that influence the positive development of the business success.

\section{Acknowledgement}

We would like to express our heartfelt appreciation and utmost gratitude to Ministry of Higher Education of Malaysia for awarding the research grant under Fundamental Research Grant Scheme to carry out this study.

\section{Corresponding Author}

${ }^{1}$ Mohamad Zulkifli Abdul Rahim

Senior Lecturer, Malaysia

Email: zulrahim@unisza.edu.my

\section{References}

\section{Al-Quran}

Abdul Rahman, Yaacob, Z., \& Mat Radzi, R. (2014a). Determinants of Successful Financial Management Among Micro Entrepreneur in Malaysia. Journal of Asian Scientific Research, 4(11), 631-639. Retrieved from http://www.aessweb.com/pdf-files/JASR-16-2014-4(11)-631-639.pdf

Abdul Rahman, Yaacob, Z., \& Mat Radzi, R. (2014b). Determinants of Successful Financial Management Among Micro Entrepreneur in Malaysia. Journal of Asian Scientific Research, 4(11), 631-639. Retrieved from http://www.aessweb.com/pdf-files/JASR-16-2014-4(11)-631-639.pdf Abdullah, S., \& Ahcene, L. (2011). The Understanding of Technology Entrepreneurship According to Shariah Principles. International Conference on Business and Economics Research, 16, 144-150. Abdullah, S., \& Mikail, S. A. (2013). Entrepreneurship and Islam: An Explortoray Study on 
INTERNATIONAL JOURNAL OF ACADEMIC RESEARCH IN BUSINESS AND SOCIAL SCIENCES

Vol. 8, No. 8, August 2018, E-ISSN: 2222-6990 @ 2018 HRMARS

Characteristics of Muslim Entrepreneur. In 5th Islamic Economics System Conference (iECONS 2013), "Sustainable Development Through The Islamic Economics System", Organized By Faculty Economics And Muamalat, Universiti Sains Islam Malaysia, Berjaya Times Square Hotel, Kuala Lumpur, 4-5th September (pp. 467-476). Kuala Lumpur. Retrieved from http://nuradli.com/iecons2013/2D-2.pdf

Adiana, N., Ahmad, A. H., Md. Rus, R., \& Zainudin, N. (2014). Modelling Small Business Failures in Malaysia. Social Science Research Network, (February), 1-10. Retrieved from http://papers.ssrn.com/sol3/papers.cfm?abstract_id=2402129

Ahmad, K., \& Mohamed Zabri, S. (2015). Factors Explaining the Use of Management Accounting Practices in Malaysian Medium-Sized Firms. Journal of Small Business and Enterprise Development, 22(4), 762-781. Retrieved from http://doi.org/10.1108/JSBED-04-2012-0057

Aishah Mohamad, S., \& Kassim, S. (2017). AN OVERVIEW OF E-PAYMENT ADOPTION AMONG MUSLIM MICRO-ENTREPRENEURS IN MALAYSIA. International Journal of Accounting Finance and Business, 2(5), 49-59. Retrieved from http://www.ijafb.com/PDF/IJAFB-2017-05-09-05.pdf

Ajuna, L. H., Nasution, M. Y., \& Yusuf, M. (2017). The Effect of Islamic Religiosity, Islamic Motivation and Islamic Work Ethics To Islamic Leadership Sharia Financial Institutions in Gorontalo Province , Indonesia. IOSR Journal Of Humanities And Social Science, 22(8), 60-65. Retrieved from http://doi.org/10.9790/0837-2208176065

Al-Aidaros, A.-H., Shamsudin, F. M., \& Idris, K. M. (2013). Ethics and Ethical Theories from an Islamic Perspective. International Journal of Islamic Thought, 4, 1. Retrieved from http://search.ebscohost.com/login.aspx?direct=true\&db=edb\&AN=93517717\&site=eds-live

Aminuddin, Z. S., Bustamam, U. S. A., Mahyuddin, M. K., \& Sathiman, S. (2016). Exploring the Concept of Al-Falāḥ (Success) in Business: an Insight From Muslim Experts. International Journal of Management, Information Technology and Engineering, 4(8), 23-36. Retrieved from http://www.bestjournals.in/view_archives.php?year=2016\&id=14\&jtype=2\&page=5

Arslan, Z. (2009). Islamic Business Ethics and Its Impact on Strategic Business Decision Making Process of Muslims. Retrieved from http://summit.sfu.ca/item/770

Ascarya, \& Rahmawati, S. (2015). Analysis the Determinants of Micro Enterprises Graduation: Analysis the Determinants of Micro Enterprises. Indonesia.

Ayala, J. C., \& Manzano, G. (2014). The Resilience of the Entrepreneur. Influence on the Success of the Business. A Longitudinal Analysis. Journal of Economic Psychology, 42, 126-135. Retrieved from http://doi.org/10.1016/j.joep.2014.02.004

Bakar, N. S., Daud, Z., Awaludin, N. S., \& Jaafar, S. (2016). Determinant of Success Factors on Performance of Sole Traders Business in Malaysia. In Proceeding of the 2nd International Conference on Economics \& Banking 2016 (2nd ICEB) (pp. 978-967). Retrieved from http://conference.kuis.edu.my/iceb2016/eproceedings/EB043.pdf

Banta, L. F. (2015). Significance of Workforce Management to Organizational Performance: A Study of Islamic Banks in Bahrain. International Journal of Engineering and Management Research, 5(55), 1-10. Retrieved from http://www.ijemr.net/DOC/SignificanceOfWorkforceManagementToOrganizationalPerforman ceAStudyOfIslamicBanksInBahrain(1-10).pdf

Baron, R. M., \& Kenny, D. A. (1986). The Moderator-Mediator Variable Distinction in Social Psychological Research: Conceptual, Strategic, and Statistical Considerations. Journal of Personality and Social Psychology, 51(6), 1173-1182. Retrieved from http://doi.org/10.1037/0022-3514.51.6.1173 
INTERNATIONAL JOURNAL OF ACADEMIC RESEARCH IN BUSINESS AND SOCIAL SCIENCES

Vol. 8, No. 8, August 2018, E-ISSN: 2222-6990 @ 2018 HRMARS

Bayrón, C. E. (2013). Social Cognitive Theory, Entrepreneurial Self-Efficacy and Entrepreneurial Intentions: Tools to Maximize the Effectiveness of Formal Entrepreneurship Education and Address the Decline in Entrepreneurial Activity. Revista, 6(1), 66-77. Retrieved from http://revistagriot.uprrp.edu/archivos/2013060105.pdf

Boso, N. (2010). Export Entrepreneurial-Oriented Behaviour and Export Performance. Lougborough University.

Bullough, A., Renko, M., \& Myatt, T. (2014). Danger Zone Entrepreneurs: The Importance of Resilience and Self-Efficacy for Entrepreneurial Intentions. Entrepreneurship: Theory and Practice, 38(3), 473-499. Retrieved from http://doi.org/10.1111/etap.12006

Callaghan, C., \& Venter, R. (2011). An investigation of the entrepreneurial orientation , context and entrepreneurial performance of inner-city Johannesburg street traders. South African Business Review, 15(1), 28-48.

Chokesikarin, V. (2014). Entrepreneurial Orientation and Customers Satisfaction : Evidences nearby Khao San Road. International Journal of Social, Behavioral, Educational, Economic, Business and Industrial Engineering, 8(1), 71-76.

Covin, J. G., \& Slevin, D. P. (1988). The influene of organization structure on the utility of an entrepreneurial top management style. Journal of Management Studies, 109(May), 321-334.

Dana, L. P., Gurau, C., \& Lasch, F. (2014). Entrepreneurship, tourism and regional development: A tale of two villages. Entrepreneurship and Regional Development, 26(3-4), 357-374. Retrieved from http://doi.org/10.1080/08985626.2014.918182

El-Annan, S. H. (2013). Innovation, Proactive, and Vision are Three Integrated Dimensions Between Leadership and Entrepreneurship. European Journal of Business and Social Sciences, 1(12), 148163. Retrieved from http://www.ejbss.com/recent.aspx

Fararah, F. S., \& Al-Swidi, A. K. (2013). The role of the perceived benefits on the relationship between service quality and customer satisfaction: A study on the Islamic microfinance and SMEs in Yemen using PLS approach. Asian Social Science, 9(10), 18-36. Retrieved from http://doi.org/10.5539/ass.v9n10p18

Frese, M., Krauss, S. I., Keith, N., Escher, S., Grabarkiewicz, R., Luneng, S. T., ... Friedrich, C. (2007). Business Owners 'Action Planning and Its Relationship to Business Success in Three African Countries. Journal of Applied Psychology, 92, 1481-1498. Retrieved from http://www.evidencebased-entrepreneurship.com/content/publications/088.pdf

Galli, L. (2013). Department for Business Innovation \& Skills: BIS Analysis Paper Number 2. SMEs: The Key Enablers of Business Success and the Economic Rationale for Government Intervention.

Ghoniyah, N., \& Hartono, S. (2014). The Role of Islamic corporate Governance in SMEs to Improve The Welfare of Society. International Journal of Economic Research, 11(3), 601-613. Retrieved from http://serialsjournals.com/serialjournalmanager/pdf/1427782909.pdf

Harif, M. A. A. M., Hoe, C. H., \& Ahmad, M. I. (2013). The Financial and Non-Financial Performance Indicators of Paddy Farmers' Organizations in Kedah. World Review of Business Research, 3(1), 80-102. Retrieved from http://www.wrbrpapers.com/static/documents/January/2013/6. Amy_new.pdf

Hariri, K., \& Osman, J. (2006). The Stages Of Entrepreneurship Personality Criteria Among Malaysian High School Students. Journal of Global Business Management, 2(1), 1-10.

Hughes, M., Eggers, F., Kraus, S., \& Hughes, P. (2015). The Relevance of Slack Resource Availability and Networking Effectiveness For Entrepreneurial Orientation. International Journal of Entrepreneurship and Small Business, 26(1), 116. Retrieved from 
INTERNATIONAL JOURNAL OF ACADEMIC RESEARCH IN BUSINESS AND SOCIAL SCIENCES

Vol. 8, No. 8, August 2018, E-ISSN: 2222-6990 @ 2018 HRMARS

http://doi.org/10.1504/IJESB.2015.071323

Hyder, S., \& Robert, L. N. (2016). Why businesses succeed or fail: a study on small businesses in Pakistan. Journal of Entrepreneurship in Emerging Economies, 8(1), 82-100. Retrieved from https://doi.org/10.1108/JEEE-03-2015-0020

Jelenc, L., Pisapia, J., \& Ivanusic, N. (2016). Demographic Variables Influencing Individual Entrepreneurial Orientation and Strategic Thinking Capability. Journal of Economic and Social Development, 3(1), 3-16. Retrieved from http://www.jesdonline.com/dokumenti/upload/separated/Vol 3 No 1_01.pdf

Kamaluddin, A., Kassim, N., Alam, M. M., Akmar, S., Samah, A., \& Bahasa, A. P. (2018). Human Capital Accountability and Construct: Evidence from Islamic Microfinance Institutions in Malaysia. Global Journal Al-Thaqafah, 117(Special Issue), 117-129. Retrieved from http: www.gjat.my

Kashif, M., Awang, Z., Walsh, J., \& Altaf, U. (2015). I'm loving it but hating US: Understanding consumer emotions and perceived service quality of US fast food brands. British Food Journal, 117(9), 2344-2360. Retrieved from http://doi.org/10.1108/BFJ-01-2015-0040

Keh, H. T., Nguyen, T. T. M., \& Ng, H. P. (2007). The Effects of Entrepreneurial Orientation and Marketing Information on the Performance of SMEs. Journal of Business Venturing, 22(4), 592611. Retrieved from http://doi.org/10.1016/j.jbusvent.2006.05.003

Lans, T., Blok, V., \& Wesselink, R. (2014). Learning Apart and Together: Towards an Integrated Competence Framework for Sustainable Entrepreneurship in Higher Education. Journal of Cleaner Production, 62, 37-47. Retrieved from http://doi.org/10.1016/j.jclepro.2013.03.036

Lucky, E. O.-I., Olesegun, A. I., \& Bakar, M. S. (2012). Determinants of Business Success : Trust or Business Policy? Journal of Arts, Science \& Commerce, 3(July 2012), 37-42.

Lumpkin, G. T., \& Dess, G. . (1996a). Clarifying the entrepreneurial orientation construcy and linking it to performance. Academy of Management Review, 21(1), 135-172. Retrieved from http://doi.org/10.2307/258632

Lumpkin, G. T., \& Dess, G. G. (1996b). Clarifying the Entrepreneurial Orientation Construct and Linking It to Performance. Academy of Management Review, 21(1), 135-172. Retrieved from http://doi.org/10.2307/258632

Lumpkin, G. T., \& Dess, G. G. (2001). Linking two dimensions of entrepreneurial orientation to firm performance: The moderating role of environment and industry life cycle. Journal of Business Venturing, 16(5), 429-451. Retrieved from http://doi.org/10.1016/S0883-9026(00)00048-3

Matchaba-Hove, T., Farrington, S., \& Sharp, G. (2015). The Entrepreneurial Orientation - Performance Relationship: a South African Small Business Perspective. The Southern African Journal of Entrepreneurship and Small Business Management, 7, 36-68. Retrieved from http://www.sajesbm.co.za/index.php/sajesbm/article/view/6

Mohamad, R., \& Mukhazir, M. R. M. (2008). Corporate Social Responsibility and Islamic Business Organizations: A Proposed Model. Islamic Finance and Business Review, 3(1), 30-42. Retrieved from http://doi.org/10.1111/j.1600-0390.2009.00128.x

Mohd Ariffin, N., Archer, S., \& Karim, R. A. A. (2007). Transparency and market discipline in Islamic banks. Advances in Islamic Economics and Finance, 1(April), 153-173.

Mohd, R., Kirana, K., Kamaruddin, B. H., Zainuddin, A., \& Ghazali, M. C. (2014). The Mediatory Effect of Self-efficacy on the Relationship between Religious Values and Entrepreneurial Orientations: A Case of Malay Owner Managers of SMEs in Manufacturing Industry. Procedia - Social and Behavioral Sciences, 130, 96-104. Retrieved from http://doi.org/10.1016/j.sbspro.2014.04.012 Musa, M. A. (2011). Islamic business ethics \& finance: An exploratory study of Islamic banks in 
INTERNATIONAL JOURNAL OF ACADEMIC RESEARCH IN BUSINESS AND SOCIAL SCIENCES

Vol. 8, No. 8, August 2018, E-ISSN: 2222-6990 @ 2018 HRMARS

Malaysia. In 8th International Conference on Islamic Economics and Finance (pp. 1-27).

Nasimi, M. H., Nasimi, S., Kasmaei, M. S., Kasmaei, H. S., Basirian, F., \& Musapour, H. (2013). Knowledge Management and Competitve Advantage for Organizations. Kuwait Chapter of Arabian Journal of Business and Management Review, 2(5), 305-323. Retrieved from http://arabianjbmr.com/pdfs/KD_VOL_2_5/7.pdf

Nason, R. S., \& Wiklund, J. (2018). An Assessment of Resource-Based Theorizing on Firm Growth and Suggestions for the Future. Journal of Management, 44(1), 32-60. Retrieved from http://doi.org/10.1177/0149206315610635

Omerzel, D. G., \& Gulev, R. E. (2011). Knowledge Resources and Competitive Advantage. International Research Journal: Winter 2011, 9(4), 335-354. Retrieved from http://www.fmkp.si/zalozba/ISSN/1581-6311/9_335-354.pdf

Piirala, P. (2012). The impact of entrepreneurial orientation on firm performance : a comparative study of Finnish and German SMEs. Retrieved from https://pdfs.semanticscholar.org/22ec/356337b5447eef570f99a8404e25d8c82dde.pdf

Pittino, D., Visintin, F., \& Lauto, G. (2017). A Configurational Analysis of the Antecedents of Entrepreneurial Orientation. European Management Journal, 35(2), 224-237. Retrieved from http://doi.org/10.1016/j.emj.2016.07.003

Putra, Y. H. S. (2014). Detecting Internal Control Problems Based on COSO and Islamic Perspective : Case on SMEs. Tazkia Islamic Finance and Business Review, 8(1), 25-44. Retrieved from http://tifbr-tazkia.org/index.php/TIFBR/article/view/60

Rafiki, A., \& Wahab, K. A. (2013). Influences of Islamic Practices on Small Firm Performance : A Study in North Sumatera , Indonesia. Islamic Management and Business, 5(11), 64-82.

Rafiki, A., \& Wahab, K. A. (2014). Islamic values and Principles in the Organization: A Review of Literature. Asian Social Science, 10(9), 1-7. Retrieved from http://doi.org/10.5539/ass.v10n9p1

Rahimli, A. (2012). Knowledge Management and Competitive Advantage. Information and Knowledge Management, 2(7), 37-43. Retrieved from http://doi.org/10.1.1.826.1852

Rahman, N. M. N. A., Abdullah, N. A., Adham, K. A., \& Mat, N. (2014). Managerial competencies: Comparing conventional and Islamic perspectives. Jurnal Pengurusan, 41, 91-99. Retrieved from http://journalarticle.ukm.my/8372/1/7769-20202-1-SM.pdf

Ratten, V., Alamanda, D. T., Ramadani, V., Hashani, M., \& Anggadwita, G. (2017). Entrepreneurial intentions from an Islamic perspective: A Study of Muslim Entrepreneurs in Indonesia. International Journal of Entrepreneurship and Small Business, 31(2), 165. Retrieved from http://doi.org/10.1504/IJESB.2017.10004845

Rauch, A., Wiklund, J., Lumpkin, G. ., \& Frese, M. (2004). Entrepreneurial Orientation and Business Performance: An Assessment of Past Research and Suggestions For the Future. Entrepreneurship: Theory and Practice, 33(3), 27-44. Retrieved from http://doi.org/10.1111/j.1540-6520.2009.00308.x

Rizki, F., Armanu, T., Surachman, \& Rofiaty. (2017). Study on the Relationship Between Islamic Leadership Style, Work Ethics, Job Satisfaction, and Employee Performance. Russian Journal of Agricultural and Socio-Economic Sciences, 1(January), 112-118.

Salehi, A., \& Roshandel Arbatani, T. (2013). Is Branding Always Beneficial? A Meta-Analysis of The Relationship between Branding And Performance in SMEs. Advances in Environmental Biology, 7(14), 4682-4688. Retrieved from http://doi.org/10.1016/j.jbusvent.2009.12.002

Salikin, N., Wahab, N. A., \& Muhammad, I. (2014). Strengths and Weaknesses among Malaysian SMEs: Financial Management Perspectives. Procedia - Social and Behavioral Sciences, 129(129), 334- 
INTERNATIONAL JOURNAL OF ACADEMIC RESEARCH IN BUSINESS AND SOCIAL SCIENCES

Vol. 8, No. 8, August 2018, E-ISSN: 2222-6990 @ 2018 HRMARS

340. Retrieved from http://doi.org/10.1016/j.sbspro.2014.03.685

Salima. Hafeez, Rashid, M., Zafar, U., \& Rehman. (2011). The Effect of Market and Entrepreneurial Orientation on Firm Performance. Information Management \& Business Review, 3(6), 389-395.

Sarif, S. M. (2016). The Influence of Taqwa in Sustainable Capacity Building. South East Asia Journal of Contemporary Business, Economics and Law, 9(2), 1-7. Retrieved from http://seajbel.com/wp-content/uploads/2016/05/K9_18.pdf

Shamsuddin, J. (2014). Malaysian SME Performance and the Government Business Support Services : The Moderating Effects of Absorptive Capacity. Othman Yeop Abdullah Graduate School of Business. Universiti Utara Malaysia.

Shein, M. L., Crous, F., \& Schepers, J. M. (2010). Positive states in Relation to Entrepreneurship Orientation. SA Journal of Industrial Psychology, 36(2), 1-10. Retrieved from http://doi.org/10.4102/sajip.v36i2.931

Suci, R. P. (2015). The Role of Job Satisfaction in Mediates Leadership Style and Work Environment to the Employees' Performance: PT POS Indonesia (Persero) Malang. International Journal of Applied Business and Economic Research, 13(9), 7081-7098.

Sulaiman, M., Sabian, N. A. A., \& Othman, A. K. (2013). The Understanding of Islamic Management Practices among Muslim Managers in Malaysia. Asian Social Science, 10(1), 189-199. Retrieved from http://doi.org/10.5539/ass.v10n1p189

Tahir, I. R., \& Abdul, M. (2013). The Role of Religious Orientation in the Business Performance of Women Owned Firms: A Preliminary Study in Malaysia Halal Food Industry. The Macrotheme Review, 2(3), 40-45.

Tehseen, S., Sajilan, S., Ramayah, T., \& Gadar, K. (2015). An Intra-Cultural Study of Entrepreneurial Competencies and SMEs Business Success in Whole Sale and Retail Industries of Malaysia: A Conceptual Model. Review Of Integrative Business Research and Economics, 4(3), 33-48.

Umrani, A. I., \& Johl, S. K. (2016). Corporate Governance, Ownership Structure and Expropriation of Rights: Case of Malaysian Small and Medium Enterprises. International Journal of Economics and Financial Issues Asia International Conference International Journal of Economics and Financial Issues, 6(6S3), 170-178.

Umrani, W. A., Mahmood, R., \& Ahmed, U. (2016). Unveiling the Direct Effect of Corporate Entrepreneurship's Dimensions on the Business Performance: A Case of Big Five Banks in Pakistan. Studies in Business and Economics, 11(1). Retrieved from http://doi.org/10.1515/sbe2016-0015

Wahab, K. A., \& Rafiki, A. (2014). Measuring Small Firm Entrepreneur's Performance Based on AlFalah. World Applied Sciences Journal, 29(12), 1532-1539. Retrieved from http://doi.org/10.5829/idosi.wasj.2014.29.12.2058

Wan Daud, N., Abdul Rahim, M., \& Mohd Nasurdin, A. (2017). Quality of Islamic Leadership and Organizational Performance within the Takaful Industry in Malaysia : A Conceptual Study. Asian Social Science, 10(21), 135-144. Retrieved from http://doi.org/10.5539/ass.v10n21p135

Wijetunge, W. A. D. S. (2016). Service Quality, Competitive Advantage and Business Performance in Service Providing SMEs in Sri Lanka. International Journal of Scientific and Research Publications, 6(7), 720-728. Retrieved from www.ijsrp.org

Wiklund, J. (1999). The Sustainability of The Entrepreneurial Orientation Performance Relationship. Entrepreneurship: Theory \& Practice, 24(1), 39-50. Retrieved from http://doi.org/Article

Wiklund, J., \& Shepherd, D. (2003). Knowledge-Based Resources, Entrepreneurial Orientation, and The Performance of Small And Medium-Sized Businesses. Strategic Management Journal, 
INTERNATIONAL JOURNAL OF ACADEMIC RESEARCH IN BUSINESS AND SOCIAL SCIENCES

Vol. 8, No. 8, August 2018, E-ISSN: 2222-6990 @ 2018 HRMARS

24(13), 1307-1314. Retrieved from http://doi.org/10.1002/smj.360

Zendehdel, M., Hj Paim, L., \& Delafrooz, N. (2016). The Moderating Effect of Culture on The Construct Factor of Perceived Risk Towards Online Shopping Behaviour. Cogent Business \& Management, 3(3), 1-13. Retrieved from http://doi.org/10.1080/23311975.2016.1223390 